Review

\title{
Population, World Production and Quality of Sheep and Goat Products
}

\author{
Mitra Mazinani and Brian Rude \\ Department of Animal and Dairy Sciences, Faculty of Agriculture, Mississippi State University, Starkville 39759 USA
}

\author{
Article history \\ Received: 06-10-2020 \\ Revised: 23-11-2020 \\ Accepted: 26-11-2020 \\ Corresponding Author: \\ Mitra Mazinani \\ Department of Animal and \\ Dairy Sciences, Faculty of \\ Agriculture, Mississippi State \\ University, Starkville 39759 \\ USA \\ Email: mm5001@msstate.edu
}

\begin{abstract}
Sheep and goats are two of the first animals that were domesticated by humans. The initial reasons for raising these animals was meat, milk and dairy products, fleece and skin. Also, one of the most important reasons for raising sheep and, goats on the farm was due to the difficulties associated with preserving animal products like meat. It was easier to keep, raise livestock and slaughter them whenever meat was required. Sheep meat production on the global scale is near 9 million tones per year and developing countries are at the top of the list. Sheep meat consumption is fourth after pork, poultry and beef meat. About $20.8 \%$ of dairy products come from sheep and goats and they make up to 1.3 and $1.9 \%$ of the total milk production in the world, respectively. Many people and infants have allergic reactions to cow's milk but not to goat's and sheep's milk and their dairy products, so there are medical benefits for goat and sheep milk. Undoubtedly, using fleece of goat and sheep is one of the main reasons for raising and developing related breeds. Carpets, bedding, upholstery and blankets are general end products of wool. Angora is a unique breed of goats that produces mohair that is suitable for knitwear, apparel, curtaining, upholstery material, shawls, socks and accessories. Global demand for small ruminant products is increasing and achieving this demand requires scientific, educational and practical infrastructures. These are mostly accomplished through organizing producer associations, access to technical services and arranging rules and policies to enhance profitable production of small ruminants and decrease obstacles.
\end{abstract}

Keywords: Goat, Sheep, Milk and Meat Production, Wool, Cashmere

\section{Introduction}

Sheep and goats are two of the first animals domesticated by humans. The domestication of goats occurred between 6,000 and 7,000 BC and the domestication of sheep was even earlier, between 11,000 and 9,000 BC (Amills et al., 2017; Aldridge et al., 2018). Sheep have been raised for thousands of years before cows. The initial reasons for raising these animals were for their meat, milk and skin. Initially, most goat and sheep breeds were developed in Southwest Asia (Chessa et al., 2009). Cheese was discovered around $8,000 \mathrm{BC}$, around the time when sheep were domesticated. Cheese is one of the most popular milk products and evolved at least 1,000 varieties and has been produced since the earliest civilizations in Classical Rome and then spread throughout the Middle East and Europe and then to North and South America and Oceania.

The main aspects that made sheep and goat appropriate for domestication were their body size, which made them more suitable for management, earlier puberty and maturity, greater reproduction rate, their social nature and obedient behavior. Also, one of the most important reasons for raising sheep and goat on the farm was due to the difficulties associated with preserving animal products like meat which is sensitive to different environments and temperatures (Clutton-Brock, 1999). Although in some aspects, goat and sheep are put in one group as small ruminants, they are different according to their chromosome number (sheep have 54 chromosomes, while goats have 60 chromosomes) and behavior. Therefore, the focus of this review is on differences 
between sheep and goat especially in population and production aspects.

\section{World Population of Sheep and Goat}

According to the FAO database (Food, 2018), the world population of sheep and goat in each continent is shown in Table 1. Asia had the largest sheep and goat population in the world compared with other continents which included 43.6 and $55.4 \%$ of world sheep and goat population, respectively. Sheep and goat populations are increasing (Fig. 1) and mostly is because of increasing worldwide demand for meat and milk (Haenlein, 2001).
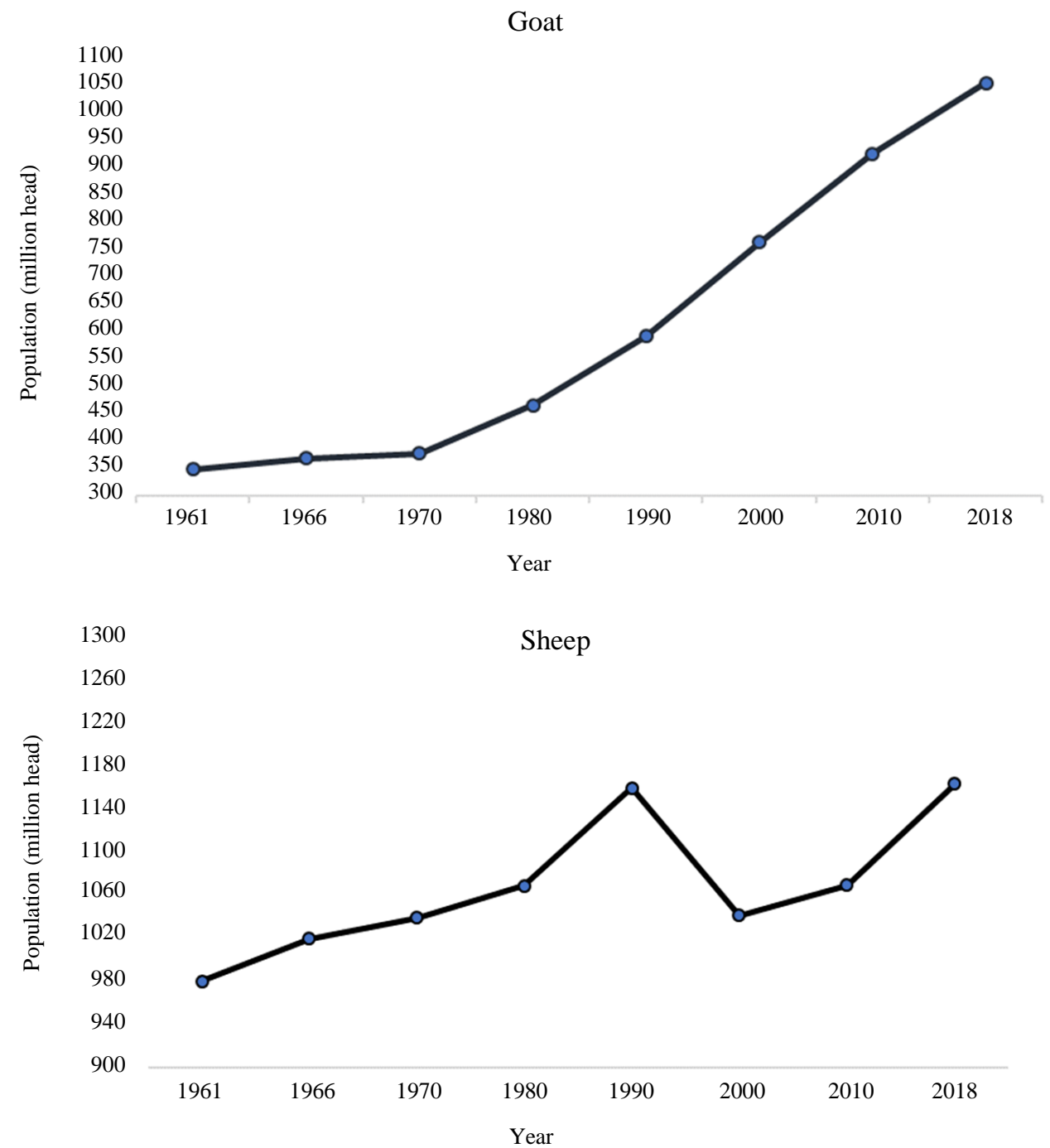

Fig. 1: Population of goat and sheep in world during 1961 to 2018 (FAOSTAT)

Table 1: Goat and sheep distribution in different areas (Food, 2018)

\begin{tabular}{llccccc}
\hline & \multicolumn{3}{c}{ Total (million head) } & \multicolumn{2}{c}{ Total (million head) } \\
Continent & Sheep & $\%$ & Countries number & Goats & \% & Countries number \\
\hline Asia & 512 & 43.6 & 45 & 556 & 55.4 & 48 \\
Africa & 352 & 30.0 & 58 & 388 & 38.7 & 59 \\
Europe & 131 & 11.2 & 46 & 17 & 1.7 & 42 \\
America & 84 & 7.1 & 46 & 48 & 0.4 & 47 \\
Oceania & 95 & 8.1 & 6 & 1,003 & 100.0 & 201 \\
Total & 1,173 & 100.0 & 192 & & & \\
\hline
\end{tabular}


Goat population in Asia was 556 million. The most goat population in Asia existed in China, India, Pakistan, Bangladesh and Mongolia. Sheep population was 512 million and countries with the largest number of sheep were China, India, Iran, Mongolia and Turkey. Africa had 388 million goats and Nigeria, Sudan, Chad, Ethiopia and Kenya had the most population of goats. Total sheep population was 352 million in Africa and Algeria, Chad, Ethiopia and Kenya were the five countries with the largest number of goats. Europe had 17 million goats and 131 million sheep. Russia, Spain, Romania, Greece and Italy were the five countries with the largest goat population and most of the sheep population in this continent were located in Spain, Germany, Russia and France. North and South America had 38 million goats. Brazil, Mexico, Argentina, Haiti and Bolivia had the largest population of goats in this continent. Sheep population was 84 million and these data were based on 46 countries. Goat population in Oceania was a little greater than 4 million head. Australia, Fiji, New Zealand, Vanuatu and French Polynesia had the most population of goats and 6 countries raise sheep in this continent with total population of 95 million head and most of them were located in Australia and New Zealand.

\section{Differences between Sheep and Goat}

Although most of the time it is assumed that goat and sheep are similar based on their management and nutritional requirements, there have some unique differences such as their chromosome number, different behavior and different management, nutrition and physiology requirements. Sheep and goats complement grazing behavior of each other as goats prefer thorny scrubland while sheep usually browse grass because it is easier for them to eat. Sheep prefer grazing hilly regions and foothills of mountains while goats prefer browsing high, bleak mountains which is one of the reasons goats are considered most versatile for their feeding habits compared with other ruminants. This behavior difference should be considered for pasture management where they are grazing, required building and facilities, farm structure and marginal activity (Mazinani et al., 2019; Miller and Lu, 2019).

In the past, goats were considered as pets, not livestock and it was thought they destroyed the pasture and they didn't get enough attention to scientific treatment (Amills et al., 2017). But raising goats showed some benefits compared to sheep, for example, goats can be milked once a day without decreasing milk production but apparently not sheep (Raynal-Ljutovac et al., 2007). The other benefit of dairy goats is their milk persistency that can be continuous for up to 2-3 years without kidding, which means that goats can provide winter milk without needing seasonal breeding (Park et al., 2006).
Also, goat and sheep are different in the terms of minerals metabolism and the maximum tolerable amounts. Goats can tolerate $300 \mathrm{mg}$ of molybdenum $/ \mathrm{kg}$ or more in daily feed intake while consuming more than $30 \mathrm{mg} / \mathrm{kg}$ molybdenum in daily feed intake is toxic for sheep. Goats can tolerate $100 \mathrm{mg} / \mathrm{kg}$ copper but sheep are more susceptible to Copper $(\mathrm{Cu})$ toxicity and recommended $\mathrm{Cu}$ for sheep is about one-tenth need of goat (Haenlein, 2001; Mazinani et al., 2019). Goats daily need to iodine is more than sheep. Supplying potassium affect on magnesium plasma in sheep but this relation between these two elements is not reported in goat. Newborn goats (kid) had more iron in their liver and blood compared to lambs (Ramírez et al., 1991).

\section{Meat}

Meat is one of the essential items in the human food pyramid that provides required nutrients like fat, protein (especially essential amino acids) and several micronutrients such as minerals and vitamins including zinc, iron and vitamin (Wyness, 2016). In developing countries, consumers are becoming aware of the relationship between eating, health and wellness. Therefore, they demand quality foods with healthpromoting properties (De Smet and Vossen, 2016). The reason of increasing interest in consuming animal products includes increasing world population, income and urbanization (Thornton, 2010).

In the past, sheep meat was considered as one of the by-products of the wool industry. However, by decreasing wool production, meat is the main reason of raising sheep and is increasing each year (Montossi et al., 2013). Sheep meat production on the global scale is near 9 million tones and developing countries are at the top of this list (Food, 2018). Consumption of sheep meat is in fourth place after pork, poultry and beef meat (OECD, 2016). Recently, human diet pattern shifts to high energy and fast foods based on animal meat. On average, annual consumption of sheep meat is about 1.7 $\mathrm{kg}$ per capita (OECD, 2016), varying from $17 \mathrm{~kg}$ in Oceania to $0.7 \mathrm{~kg}$ in North America (Montossi et al., 2013). China is on top of the list for consumption of sheep meat with $46 \%$ of the world sheep meat consumption because of its large human population that needs to provide a variety of animal products. Australia, New Zealand, India, Middle East and parts of Europe use sheep meat as the main source of protein (Sañudo et al., 2013; Dairy, 2016). Most of the population in developing countries especially in rural areas depends on goat meat production as an important source of food and income.

Different factors can affect meat quality that are included animal age, sex, fat and protein percent, consumed diet, physiology and also animal genetics which can affect metabolism and tissue features (Webb et al., 
2005). Breed can influence some fractions of meat. For example, some breeds have greater intramuscular fat compared to other breeds not modified for meat production and usually have a greater amount of muscle (Arvizu et al., 2011). In the other aspect, breed can effect true protein and nitrogen content of meat (Esenbuga et al., 2009). One of the main factors that influence profile of fatty acids in animals' meat is diet. Therefore, by manipulating sheep diet like adding healthful fatty acids, this goal can be achieved (De Smet and Vossen, 2016). The growth curve of sheep is sigmoid and it has a period of accelerated for lean tissue that occurs simultaneously with puberty. Increasing protein and fat deposition are known in puberty stage. This raise of protein deposition is mediated by Growth Hormone (GH), which increase muscle fiber via hypertrophy and alleviate fat deposition. Increasing fat deposition is also regulated by certain sex hormones (Gerrard and Grant, 2003). The quality of sheep meat will change in different ages that is associated with the physical and chemical changes of carcass. Santos and Huber (1996) observed female lambs meat had greater fat content compared to male lambs (2.3 Vs. $1.9 \%$ respectively). Rodríguez et al. (2008) also found that overall body fat composition was $1.6 \%$ in males and $2.9 \%$ in female lambs.

Ruminant can biohydrogenate fatty acids in their diet that cause increasing Saturated Fatty Acids (SFA) in their meat. Biohydrogenation in cattle is usually greater than sheep, therefore, beef meat contains a greater amount of Polyunsaturated Fatty Acids (PUFA) and its related intermediates such as conjugated linoleic acid. Also, sheep meat contains a greater proportion of Branched-Chain FA (BCFA). It is known that SFA and Trans Monounsaturated Fatty Acids (MUFA) may have negative effects on the profile of lipids in blood and can cause major metabolic disorders such as diabetes and cardiovascular problems. These negative effects can impact on meat consumption and animal source acceptability.

On the other hand, ruminant meat is a source of PUFA biohydrogenation intermediates especially Conjugated Linoleic Acid (CLA), omega 3 PUFAs, BCFA which are known for their positive effects on human health (Field et al., 2009; Ran-Ressler et al., 2014). Also, FA is one of the key factors effects on meat texture and flavor (Watkins et al., 2014). Diet is a major factor which influences the profile of meat and the FA composition of animals. In this regard, it is possible to modify and enrich ruminant meat and provide high-quality products for consumers by manipulating their diet (De Smet and Vossen, 2016). Therefore, considering health benefits, sheep meat has the potential for providing enriched foods as it is influenced by many different factors and one of them is FA that can promote human health.

Most of the goats in the world are reared for meat. Goat meat has some differences from sheep meat based on flavor and aroma and tends to be less tender and less juicy compare with lamb and mutton. Although, by preserving them this flavor will be reduced (Webb et al., 2005). The chemical composition and quality of goat meat indicated that lamb meat is not nutritionally superior to goat meat. Compared with sheep carcasses, goats are usually less compact and are leaner and smaller than sheep. Like sheep meat, goat meat can be affected by age, breed, diet and sex (Sheridan et al., 2003).

Less preference for goat meat is related to the difference between sheep and goat's meat solubility, collagen content and muscle fiber characteristics. Goat meat has more collagen content and less solubility with more fibrous residues and coarse texture (Sheridan et al., 2003). Fat deposition in goat occurs very late and usually occurs when the animals are at their mature body weight (Owen et al., 1983). Goat carcasses are susceptible to lose more moisture during chilling and this loss tends to be greater in smaller carcasses compared to larger carcasses (Simela et al., 2000).

Goat meat has a greater concentration of methionine, lysine, isoleucine, arginine, tryptophan and threonine than pork, beef and sheep meat (Pellett and Young, 1990). Compared to beef and sheep meat, goat has less fat and saturated fat content and greater PUFA (Anaeto et al., 2010; Aghwan et al., 2014). Based on that, goat meat should be considered healthier than other ruminant meats. As it shown in the Table 2, compared to other meats, such as beef, lamb, pork and chicken meat, goats have less fat, cholesterol and calories. Based on greater nutritional value and greater unsaturated fatty acid to saturated fatty acid ratio, goat meat has the potential for improving human health and reducing obesity risk and related metabolic diseases (Shija et al., 2013; Malekian et al., 2014). This field of study needs more research on how to modify and enrich meat to achieve meat products that meet consumer's desire.

Table 2: Goat meat nutrient composition compares with other meat sources (Food, 2018)

\begin{tabular}{lllllll}
\hline Per 85 g cooked/roasted & Calories (Kcal) & Fat $(\mathrm{g})$ & Saturated fat $(\mathrm{g})$ & Cholesterol $(\mathrm{mg})$ & Protein $(\mathrm{g})$ & Iron $(\mathrm{mg})$ \\
\hline Goat & 122 & 2.8 & 0.79 & 63.8 & 23 & 3.2 \\
Chicken & 162 & 6.3 & 1.7 & 76.0 & 25 & 1.5 \\
Beef & 179 & 7.9 & 3.0 & 73.1 & 25 & 2.9 \\
Pork & 180 & 8.2 & 2.9 & 73.2 & 25 & 2.7 \\
Lamb & 175 & 8.1 & 2.9 & 78.2 & 24 & 1.4 \\
\hline
\end{tabular}




\section{Milk}

Dairy goat and sheep accounts for $20.8 \%$ of world goat and sheep population. However, they produce $1.3 \%$ and $1.9 \%$ of the world's total milk production while milk produced by cattle is $83.1 \%$ (Food, 2018). In Asia, goat milk is used locally and usually not sold commercially. Most commercial markets for dairy goat production are in European countries like Spain, Greece, France and the Netherlands (Liang and Paengkoum, 2019). Goat milk production is growing in the USA, because of increasing demands for goat dairy products, especially cheese or chevre. According to this, the dairy goat population doubled from 1997 to 2012 (Bredesen, 2018). Goat milk has less sodium, iron, zinc, sulfur, molybdenum, ribonuclease, lipase, alkaline phosphatase, xanthine oxidase, $\mathrm{N}$-acetylneuraminic acid, orotic acid, folate, pyridoxine, vitamins $\mathrm{C}$ and B12, compared to cow milk. Goat milk has less freezing point and $\mathrm{pH}$ (Haenlein, 2001). Goat milk is more similar to human milk than cow's milk and can be digested more easily because fat globules are smaller and have different casein types which are digesting easier, these characteristics cause goat curd to be softer. Milk from goat and cow have the same carnitine content, but in sheep milk carnitine is almost eight times greater (Wendorff, 2005). Europe and North America have used genetic selection of dairy goats to improve their milk production and increase lactation periods. They exported high producing breeds to developing countries but reaching their genetic potential needs further research and evaluation (World Health Organization, 2008).

Sheep milk is more different from cow milk compared to goat milk that is shown in Table 3. Sheep milk has more solids, protein, lactose and fat. Goat milk has less lactose than sheep and cow milk but greater in other content compared to cow milk (Raynal-Ljutovac et al., 2007). The increased fat content of sheep milk makes it ideal for producing cheese and yogurt than either goat or cow milk. Chemical composition of sheep milk can be affected by several factors, like breed, age, diet, parity, season, stage of lactation, temperature, lactation efficiency and udder diseases like mastitis (Watkins et al., 2014). Changes in the forage source and composition during different seasons can affect lipid and fatty acid composition of sheep milk (Revilla et al., 2017). The average size of fat globules in sheep and goat milk is smaller than cow milk which are 3.0, 3.6 and $4.0 \mu \mathrm{m}$, respectively. These smaller size and greater fat globule dispersion make it suitable for long term freezing without separating (Balthazar et al., 2017). Due to small fat globules dispersed in sheep milk, it has a creamy texture and easily digested (Park and Pariza, 2007). Dairy sheep milk products are generally cheese and whey cheese because of a greater percentage of protein,

fat and calcium (Barłowska et al., 2011). Milk production of sheep is not a large amount due to seasonality production, but it can be frozen and stored for up to 12 months before being used for dairy products (Wendorff, 2001; Albenzio et al., 2016).

Casein amount and micelle characteristics are different among goat, sheep and cattle milk. Mineralization degrees of sheep and goat milk casein micelles is greater than cow and they are less stable in warm temperatures (Raynal-Ljutovac et al., 2007). Sheep milk has more calcium in casein micelles, this is a technological advantage because there is no need to add $\mathrm{CaCl}_{2}$. Also, compared to cow and goat milk, sheep milk requires less rennin for producing curd (Wendorff, 2005). Sheep milk has greater amounts of lysine, alanine, histidine, serine and valine but contains less glycine and cystine compare to cow milk (Molik et al., 2012).

Table 3: Milk composition in different species

\begin{tabular}{|c|c|c|c|}
\hline Composition & Goat & Sheep & Cow \\
\hline Fat $(\%)$ & 3.8 & 7.9 & 3.6 \\
\hline Solids-not-fat (\%) & 8.9 & 12.0 & 9.0 \\
\hline Lactose $(\%)$ & 4.1 & 4.9 & 4.7 \\
\hline Protein $(\%)$ & 3.4 & 6.2 & 3.2 \\
\hline Casein $(\%)$ & 2.4 & 4.2 & 2.6 \\
\hline Albumin, globulin (\%) & 0.6 & 1.0 & 0.6 \\
\hline Non-protein N (\%) & 0.4 & 0.8 & 0.2 \\
\hline Ash $(\%)$ & 0.8 & 0.9 & 0.7 \\
\hline Calories/100 mL & 70 & 105 & 69 \\
\hline \multicolumn{4}{|l|}{ Mineral } \\
\hline $\mathrm{Ca}(\mathrm{mg})$ & 134 & 193 & 122 \\
\hline $\mathrm{P}(\mathrm{mg})$ & 121 & 158 & 119 \\
\hline $\operatorname{Mg}(\mathrm{mg})$ & 16 & 18 & 12 \\
\hline $\mathrm{K}(\mathrm{mg})$ & 181 & 136 & 152 \\
\hline $\mathrm{Na}(\mathrm{mg})$ & 41 & 44 & 58 \\
\hline $\mathrm{Cl}(\mathrm{mg})$ & 150 & 160 & 100 \\
\hline $\mathrm{S}(\mathrm{mg})$ & 28 & 29 & 32 \\
\hline $\mathrm{Fe}(\mathrm{mg})$ & 0.07 & 0.08 & 0.08 \\
\hline $\mathrm{Cu}(\mathrm{mg})$ & 0.05 & 0.04 & 0.06 \\
\hline $\mathrm{Mn}(\mathrm{mg})$ & 0.032 & 0.007 & 0.02 \\
\hline $\mathrm{Zn}(\mathrm{mg})$ & 0.56 & 0.57 & 0.53 \\
\hline $\mathrm{I}(\mathrm{mg})$ & 0.022 & 0.020 & 0.021 \\
\hline $\mathrm{Se}(\mu \mathrm{g})$ & 1.33 & 1.00 & 0.96 \\
\hline $\mathrm{Al}(\mathrm{mg})$ & n.a. & $0.05-0.18$ & n.a. \\
\hline \multicolumn{4}{|l|}{ Vitamin } \\
\hline Vitamin A (IU) & 185 & 146 & 126 \\
\hline Vitamin D (IU) & 2.3 & $0.18 \mu \mathrm{g}$ & 2.0 \\
\hline Thiamine (mg) & 0.068 & 0.08 & 0.045 \\
\hline Riboflavin (mg) & 0.21 & 0.376 & 0.16 \\
\hline Niacin $(\mathrm{mg})$ & 0.27 & 0.416 & 0.08 \\
\hline Pantothenic acid (mg) & 0.31 & 0.408 & 0.32 \\
\hline Vitamin B6 (mg) & 0.046 & 0.08 & 0.042 \\
\hline Folic acid $(\mu \mathrm{g})$ & 1.0 & 5.0 & 5.0 \\
\hline Biotin $(\mu \mathrm{g})$ & 1.5 & 0.93 & 2.0 \\
\hline Vitamin B12 ( $\mu \mathrm{g})$ & 0.065 & 0.712 & 0.357 \\
\hline Vitamin C (mg) & 1.29 & 4.16 & 0.94 \\
\hline
\end{tabular}


Many people, including infants, have allergic reactions to cow's milk but not to goat and sheep milk and their related dairy products so there is a medical benefit for using these non-cow milk products (Haenlein and Caccese, 1984). Increased requests for healthier dairy products have led to a renewed interest in different species' products. The differences between the species milk content deserve more research attention for better understanding and this information could be used for improving dairy products such as yogurt and cheese. Therefore, this understanding can be used to enhance quality of these unique products as well as increasing the appeal of consuming small ruminant dairy products in societies (Haenlein, 2001).

\section{Sheep Wool}

Human needs for clothing and protection from cold weather were the main reasons of raising and developing wool breeds of sheep. Carpet, bedding, upholstery and blankets are general wool products (World Health Organization, 2008). Sheep is the main animal used for producing wool. Like all sheep products, the dominance of wool sheep belongs to Asia, Australia and New Zealand. In recent decades, wool production suffered from an economic crisis due to the use of synthetic fibers, also consumer attitude about animal welfare affecting wool trade markets (Hustvedt et al., 2013).

Skin is one of the by-products of meat production and the amount of hiding available is influenced by number of animals and amount of meat production. Asia is the major skin producer in the world and Africa is second. The primary reason of raising certain breeds for sheep such as Karakul is to produce wool. Wool production is influenced by several factors such as environmental situation, protein, zinc and copper intake, genotype and physiology (Bottomley, 1979; Yeates et al., 2013). The annual wool production by sheep is between 2 to 5 $\mathrm{kg} / \mathrm{head}$ (Robards, 1979) and is depends on breed. Some wool-breeds such as Lincoln and Merino produce 22 to 23 g dry wool per day (Daly and Carter, 1955; Hogan et al., 1979).

It is known that feed intake has a large effect on sheep wool growth (three to four times changes in wool growth rate). Especially high producing sheep had better respond to increasing feed intake. There is a positive linear relationship between wool growth and dry matter intake digestibility (Allden, 1979).

\section{Cashmere and Mohair}

Goats produce two kinds of fiber known as guard hair and down hair. Guard hair covers the animal body while down hair protects the animal from cold weather. Down hair is known as cashmere. Production of cashmere fiber is usually about $500 \mathrm{~g}$ to $1 \mathrm{~kg} / \mathrm{head}$ annually and can be used to make clothes and fabrics (Tuncer, 2018). Different factors like herd intensity, birth status, sex and age can affect cashmere production (Wang et al., 2013). It has been shown cashmere growth is influenced by melatonin during the non-growing period that increased cashmere yield and length 34.5 and $21.3 \%$, respectively (Duan et al., 2015). Cashmere fibers are considered beautiful, soft (softer than wool), bright, durable and elastic and these features make them more desirable to the textile industry (Shakyawar et al., 2013).

Angora is a unique breed of goat which produces mohair. The Angora breed has a single coat of long, lustrous and relatively coarse, but non-hairy fibers. Mohair is quite different from cashmere, it is lustrous, long and coarse. Mohair must be harvested by shearing because the Angora have lost the ability to molt (Ryder, 1990a-b). Mohair is suitable for knitwear, apparel, curtaining, upholstery material, shawls, socks and accessories (Hunter, 1993). Several countries produce mohair, that more than $60 \%$ of them are in Southern Africa (Forti and Hemrard, 2014).

As mentioned, sheep and goat fleece are affected by various factors, so conducting more research in this field and using the results of research can increase information and ability to produce better and more desirable products.

\section{Conclusion}

Demand for livestock products has increased by growing human population and urbanization and probably will continue for at least the next three decades. The potential of sheep and goat industry in developing countries is quite promising but needs more investment in livestock production marketing and related research. On the other hand, benefits of using sheep and goat products needs to be more effectively introduced to consumers. Scientific and technological research in breeding, management, nutrition and disease control should continue to increase economic benefit of sheep and goat production. Complying consumer demands need to increase intensive farms. Also, different aspects of shifting smallholders and agropastoral systems to intensive farms on neutral resource and water must be considered comprehensively. Governments can set supportive mechanisms for producers and also make rules and policies to enhance standard level of raising these animals.

\section{Acknowledgment}

The authors would like to thank Department of Animal and Dairy Sciences of the Mississippi State University for their help. 


\section{Authors' Contribution}

Mitra Mazinani: Participated in all experiments, coordinated the data-analysis and contributed to the writing of the manuscript.

Brian Rude: Contributed in drafting the article and reviewing it critically for significant intellectual content.

\section{Animal Welfare Statement}

All the authors confirm that the ethical policies of the journal as mentioned in the journal's author guidelines have been adhered to. No ethical approval was required as this is a review article with no original research data.

\section{Ethics}

This article is original and contains unpublished material. The corresponding author confirms that all of the other authors have read and approved the manuscript and no ethical issues involved.

\section{References}

Aghwan, Z. A., Alimon, A. R., Goh, Y. M., Nakyinsige, K., \& Sazili, A. Q. (2014). Fatty acid profiles of supraspinatus, longissimus lumborum and semitendinosus muscles and serum in kacang goats supplemented with inorganic selenium and iodine. Asian-Australasian journal of animal sciences, 27(4), 543.

Albenzio, M., Santillo, A., Avondo, M., Nudda, A., Chessa, S., Pirisi, A., \& Banni, S. (2016). Nutritional properties of small ruminant food products and their role on human health. Small Ruminant Research, 135, 3-12.

Aldridge, M. E., Fearon, J. E., Haynes, B. P., Miller, H. M., Sanford, K. Y., Scott, R. R., ... \& Franks, B. R. (2018). Solutions For Grand Challenges In Goat And Sheep Production. Biotropia, 26(1), 55-64.

Allden, W. G. (1979). Feed intake, diet composition and wool growth. Physiological and environmental limitations to wool growth'.(Eds JL Black, PJ Reis) pp, 61-78.

Amills, M., Capote, J., \& Tosser-Klopp, G. (2017). Goat domestication and breeding: a jigsaw of historical, biological and molecular data with missing pieces. Animal genetics, 48(6), 631-644.

Anaeto, M., Adeyeye, J. A., Chioma, G. O., Olarinmoye, A. O., \& Tayo, G. O. (2010). Goat products: Meeting the challenges of human health and nutrition. Agric Biol JN Am, 6, 1231-1236.

Anifantakis, E. M., Rosakis, B., \& Ramou, C. (1980). Travaux Scientifiques de l'Institut Technologique Superieur des Industries Alimentaires (Scientific work of the Technology Institut for Nutrition Industries). Plovdiv, Bulgaria, Tom, XXVII, CB1.
Arvizu, R. R., Domínguez, I. A., Rubio, M. S., Bórquez, J. L., Pinos-Rodríguez, J. M., González, M., \& Jaramillo, G. (2011). Effects of genotype, level of supplementation and organic chromium on growth performance, carcass and meat traits grazing lambs. Meat Science, 88(3), 404-408.

Balthazar, C. F., Silva, H. A., Vieira, A. H., Neto, R. P. C., Cappato, L. P., Coimbra, P. T., ... \& Freitas, M. Q. (2017). Assessing the effects of different prebiotic dietary oligosaccharides in sheep milk ice cream. Food Research International, 91, 38-46.

Barłowska, J., Szwajkowska, M., Litwińczuk, Z., \& Król, J. (2011). Nutritional value and technological suitability of milk from various animal species used for dairy production. Comprehensive reviews in food science and food safety, 10(6), 291-302.

Bottomley, G. A. (1979). Weather conditions and wool growth. Physiological and environmental limitations to wool growth'.(Eds JL Black, PJ Reis) pp, 115-126.

Bredesen, S. T. (2018). All joking aside goats step from comic relief to dairy spotlight. Progressive Dairyman, 2018 [cited 2019 Feb 16].

Chessa, B., Pereira, F., Arnaud, F., Amorim, A., Goyache, F., Mainland, I., ... \& Alberti, A. (2009). Revealing the history of sheep domestication using retrovirus integrations. Science, 324(5926), 532-536.

Clutton-Brock, J. (1999). A natural history of domesticated mammals. Cambridge University Press.

Coni, E., Bocca, B., \& Caroli, S. (1999). Minor and trace element content of two typical Italian sheep dairy products. Journal of dairy research, 66(4), 589-598.

Dairy, A. H. D. B. (2016). Dairy Statistics: An Insider's Guide 2016. AHDB Dairy, Stoneleigh.

Daly, R. A., \& Carter, H. B. (1955). The fleece growth of young Lincoln, Corriedale, Polwarth and fine Merino maiden ewes under housed conditions and unrestricted and progressively restricted feeding on a standard diet. Australian Journal of Agricultural Research, 6(4), 476-513.

De Smet, S., \& Vossen, E. (2016). Meat: The balance between nutrition and health. A review. Meat Science, 120, 145-156.

Debski, B., Picciano, M. F., \& Milner, J. A. (1987). Selenium content and distribution of human, cow and goat milk. The Journal of nutrition, 117(6), 1091-1097.

Duan, C., Xu, J., Sun, C., Jia, Z., \& Zhang, W. (2015). Effects of melatonin implantation on cashmere yield, fibre characteristics, duration of cashmere growth as well as growth and reproductive performance of Inner Mongolian cashmere goats. Journal of Animal Science and Biotechnology, 6(1), 1-6. 
Esenbuga, N., Macit, M., Karaoglu, M., Aksakal, V., Aksu, M. I., Yoruk, M. A., \& Gul, M. (2009). Effect of breed on fattening performance, slaughter and meat quality characteristics of Awassi and Morkaraman lambs. Livestock Science, 123(2-3), 255-260.

Field, C. J., Blewett, H. H., Proctor, S., \& Vine, D. (2009). Human health benefits of vaccenic acid. Applied Physiology, Nutrition and Metabolism, 34(5), 979-991.

Food, F. A. O. (2018). Agriculture Organization of the United Nations. FAOSTAT: statistics database.

Forti, R., \& Hemrard, M. (2014). Agriculture, Forestry and Fishery Statistics: Roundwood, Fuelwood and Other Basic Products. Luxembourg: EUROESTAT.

Gerrard, D. E., \& Grant, A. L. (2003). Principles of animal growth and development. Kendall Hunt.

Haenlein, G. F. W. (2001). Past, present and future perspectives of small ruminant dairy research. Journal of Dairy Science, 84(9), 2097-2115.

Haenlein, G. F. W., \& Caccese, R. (1984). Goat milk versus cow milk. Goat Extension Handbook/George FW Haenlein, Donald L. Ace, editors.

Hogan, J. P., Elliott, N. M., \& Hughes, A. D. (1979). Maximum wool growth rates expected from Australian Merino genotypes.

Hunter, L. (1993). Mohair-A review of its properties, processing and applications. CSIR Division of Textile Technology, Port Elizabeth. International Mohair Association.

Hustvedt, G., Carroll, K. A., \& Bernard, J. C. (2013). Consumer ethnocentricity and preferences for wool products by country of origin and manufacture. International Journal of Consumer Studies, 37(5), 498-506.

Jenness, R. (1980). Composition and characteristics of goat milk: review 1968-1979. Journal of Dairy Science, 63(10), 1605-1630.

Liang, J. B., \& Paengkoum, P. (2019). Current status, challenges and the way forward for dairy goat production in Asia-conference summary of dairy goats in Asia. Asian-Australasian Journal of Animal Sciences, 32(8), 1233.

Malekian, F., Khachaturyan, M., Gebrelul, S., \& Henson, J. F. (2014). Composition and fatty acid profile of goat meat sausages with added rice bran. International journal of food science, 2014.

Mazinani, M., Naserian, A. A., Mesgaran, M. D., \& Valizadeh, R. (2019). Determination of coated urea releasing in ruminant's rumen through in vivo and in vitro studies. Iranian Journal of Animal Science Research, 11(2).

Miller, B. A., \& Lu, C. D. (2019). Current status of global dairy goat production: an overview. AsianAustralasian journal of animal sciences, 32(8), 1219.
Molik, E., Bonczar, G., Misztal, T., Żebrowska, A., \& Zięba, D. (2012). The effect of the photoperiod and exogenous melatonin on the protein content in sheep milk. Milk Protein, 325.

Montossi, F., Font-i-Furnols, M., Del Campo, M., San Julián, R., Brito, G., \& Sañudo, C. (2013). Sustainable sheep production and consumer preference trends: Compatibilities, contradictions and unresolved dilemmas. Meat science, 95(4), 772-789.

OECD, F. (2016). FDI in Figures. Paris: Organisation for European Economic Cooperation.

Owen, J. E., Cereceres, M. T. A., Macias, J. G., \& Gonzalez, F. N. (1983). Studies on the Criollo goat of Northern Mexico: Part 1-The effects of body weight on body components and carcass development. Meat Science, 9(3), 191-204.

Park, Y. W., \& Chukwu, H. I. (1989). Trace mineral concentrations in goat milk from French-Alpine and Anglo-Nubian breeds during the first 5 months of lactation. Journal of Food Composition and Analysis, 2(2), 161-169.

Park, Y. W., Haenlein, G. F., \& Wendorff, W. L. (2006). Overview of milk of non-bovine mammals. Handbook of milk of non-bovine mammals, $3 \mathrm{e} 9$.

Park, Y., \& Pariza, M. W. (2007). Mechanisms of body fat modulation by conjugated linoleic acid (CLA). Food Research International, 40(3), 311-323.

Pellett, P. L., \& Young, V. R. (1990). Role of meat as a source of protein and essential amino acids in human protein nutrition. Advances in meat research (USA).

Posati, L. P., \& Orr, M. L. (1976). Composition of Foods--Dairy and Egg Products: Raw, Processed, Prepared (No. 8). Agricultural Research Service, US Department of Agriculture.

Ramírez, R. G., Loyo, A., Mora, R., Sanchez, E. M., \& Chaire, A. (1991). Forage intake and nutrition of range goats in a shrubland in northeastern Mexico. Journal of Animal Science, 69(3), 879-885.

Ran-Ressler, R. R., Bae, S., Lawrence, P., Wang, D. H., \& Brenna, J. T. (2014). Branched-chain fatty acid content of foods and estimated intake in the USA. British journal of nutrition, 112(4), 565-572.

Raynal-Ljutovac, K., Park, Y. W., Gaucheron, F., \& Bouhallab, S. (2007). Heat stability and enzymatic modifications of goat and sheep milk. Small Ruminant Research, 68(1-2), 207-220.

Revilla, I., Escuredo, O., González-Martín, M. I., \& Palacios, C. (2017). Fatty acids and fat-soluble vitamins in ewe's milk predicted by near infrared reflectance spectroscopy. Determination of seasonality. Food chemistry, 214, 468-477.

Robards, G. E. (1979). Regional and seasonal variation in wool growth throughout Australia. Physiological and Environmental Limitations to Wool Growth.'(Eds JL Black and P. J. Reis.) pp, 1-42. 
Rodríguez, A. B., Landa, R., Bodas, R., Prieto, N., Mantecón, A. R., \& Giráldez, F. J. (2008). Carcass and meat quality of Assaf milk fed lambs: Effect of rearing system and sex. Meat Science, 80(2), 225-230.

Ryder, M. L. (1990a). The production of goat fibres. In Proc. 2nd Inter. Symp. Speciality Animal Fibers (pp. 175-194).

Ryder, M. L. (1990b). Goat fibre and its production. In Proc. 8th Int. Wool Textile Research Conf. New Zealand (Vol. 11, pp. 241-266).

Santos, F. P., \& Huber, J. T. (1996). Quality of bypass proteins fed to high-producing cows is important. Feedstuffs (USA).

Sañudo, C., Muela, E., \& del Mar Campo, M. (2013). Key factors involved in lamb quality from farm to fork in Europe. Journal of Integrative Agriculture, 12(11), 1919-1930.

Shakyawar, D. B., Raja, A. S. M., Kumar, A., Pareek, P. K., \& Wani, S. A. (2013). Pashmina fibreProduction, characteristics and utilization.

Sheridan, R., Hoffman, L. C., \& Ferreira, A. V. (2003). Meat quality of Boer goat kids and Mutton Merino lambs 2. Sensory meat evaluation. Animal Science, 76(1), 73-79.

Shija, D. S., Mtenga, L. A., Kimambo, A. E., Laswai, G. H., Mushi, D. E., Mgheni, D. M., ... \& Safari, J. G. (2013). Chemical composition and meat quality attributes of indigenous sheep and goats from traditional production system in Tanzania. AsianAustralasian journal of animal sciences, 26(2), 295.

Simela, L., Gumede, S., Ndlovu, L. R., \& Sibanda, L. M. (2000). Handling losses of Matebele goats marketed through a commercial abattoir. Improvement of market orientated small ruminant production systems and sustainable land use in semi-arid regions of Southern Africa. Project TS3*-CT94-0312 Final Technical Report, 147-156.
Thornton, P. K. (2010). Livestock production: recent trends, future prospects. Philosophical Transactions of the Royal Society B: Biological Sciences, 365(1554), 2853-2867.

Tuncer, S. S. (2018). Some cashmere characteristics of hair goats raised in Van province. Austral journal of veterinary sciences, 50(3), 125-128.

Wang, Z., Wang, R., Zhang, W., Wang, Z., Wang, P., Liu, H., ... \& Zhang, Y. (2013). Estimation of genetic parameters for fleece traits in yearling Inner Mongolia Cashmere goats. Small Ruminant Research, 109(1), 15-21.

Watkins, P. J., Kearney, G., Rose, G., Allen, D., Ball, A. J., Pethick, D. W., \& Warner, R. D. (2014). Effect of branched-chain fatty acids, 3-methylindole and 4methylphenol on consumer sensory scores of grilled lamb meat. Meat Science, 96(2), 1088-1094.

Webb, E. C., Casey, N. H., \& Simela, L. (2005). Goat meat quality. Small ruminant research, 60(1-2), 153-166.

Wendorff, W. L. (2001). Freezing qualities of raw ovine milk for further processing. Journal of Dairy Science, 84, E74-E78.

Wendorff, W. L. (2005). Sheep Milk and Milk Production: Processing and Marketing. In Encyclopedia of Animal Science (pp. 794-796).

World Health Organization. (2008). Microbiological Hazards in Fresh Leafy Vegetables and Herbs: Meeting Report (Vol. 14). Food \& Agriculture Org.

Wyness, L. (2016). The role of red meat in the diet: nutrition and health benefits. Proceedings of the Nutrition Society, 75(3), 227-232.

Yeates, N. T., Edey, T. N., \& Hill, M. K. (2013). Animal Science: reproduction, climate, meat, wool. Elsevier. 